Check for updates

Newcastle-upon-Tyne, UK

stokel@gmail.com

Cite this as: BMJ 2021;372:n327

http://dx.doi.org/10.1136/bmi.n327

Published: 08 February 2021

\section{Covid-19: Why test and trace will fail without support for self-isolation}

\author{
The spread of SARS-CoV-2 will only slow if people who test positive for the virus self-isolate. But \\ expecting them to do so is a bigger ask than governments seem to realise. Chris Stokel-Walker \\ reports
}

\section{Chris Stokel-Walker freelance journalist}

Carina Marquez was surprised to see the Latino man return to the test site she was running in San Francisco. He'd received a positive test result but had come back seeking advice.

"I think he was probably undocumented and still had to go to work," says Marquez, associate professor in the school of medicine at the University of California, San Francisco, and an infectious disease expert. "He was very nervous to tell his boss and was totally conflicted." Presenting only mild symptoms, he reasoned he couldn't be that infectious. The patient was torn between going to work to earn money for his family and doing right by his community by isolating.

For millions worldwide, a positive coronavirus test isn't just a medical blow but a financial one too. Internal UK government polling suggests just $17 \%$ of people showing symptoms are subjecting themselves to tests, for fear that a positive result and the ensuing self-isolation will lose them money.

It's the same quandary Marquez's patient in San Francisco faced-until she gave him a $\$ 500$ ( $£_{366}$; $€$ 416) gift card to support his family. It's part of a Californian system implemented by primary care doctors and lawmakers, called the Right to Recover Act, to encourage the city's least wealthy to come forward for testing, funded mostly through philanthropic donations.

The policy was designed to counteract people shying away from coronavirus testing for fear they'd lose income and slip into poverty. In an October 2020 paper for Plos One, Marquez and colleagues evaluated the scheme's success, finding it helped encourage people to self-isolate.

"All of a sudden he relaxed," she says of her visitor. "He said: 'Okay, I can do it.' Before that he was like, 'I don't know.' It was a powerful thing to see."

\section{Test, trace, isolate}

While functioning test and trace systems have stuttered into life with differing degrees of speed, depending on the country, support for people forced to self-isolate has universally lagged.

"What's driving the majority of background community transmission is non-modifiable by individual choices," says Muge Cevik, co-author of a recent editorial in The BMJ, who researches infectious diseases at the University of St Andrews. "Economically marginalised communities generally cannot simply choose immediately to modify their transmission networks through changes to their living or working contexts in the absence of specific support."

Covid-19 is known to have disproportionately affected the poorest in society, often in jobs that either cannot be done from home or are unstable, or in industries such as hospitality that are not stable enough to survive the closures that lockdowns and social distancing have wrought. To stop working and isolate is to cut off your livelihood with immediate effect.

It's not that they aren't reaching out for help either: the UK Labour Party says nearly three quarters of people who applied for discretionary grants from local councils were denied the funding despite being asked to self-isolate by the NHS Test and Trace app.

And it's not only financial support to stop working that's needed. People also need help to prevent spreading the virus to others in their households. This is a concern for those needing to self-isolate who have tested positive or been in contact with a positive case, as well as for NHS staff and other key workers who want to protect their families from potential exposure. Or indeed those who live in accommodation too small or unsuitable to isolate properly from the rest of the household.

Just one in eight people in the UK live alone, according to the Office for National Statistics. In London, $6.2 \%$ of households contain two or more unrelated adults. Within-household transmission is "very common," according to the Scientific Pandemic Influenza Group on Modelling (SPI-M), which advises the UK government, but can be mitigated in part by offering a "comprehensive package of information and support."

Yet government systems put in place to support those asked to self-isolate do not match what SPI-M says is needed. Without support, self-isolation-a key pillar of the test, track, and isolate plan to slow the spread of covid-19-simply doesn't work.

\section{Hotels to the rescue}

Self-isolation can be difficult even with financial support, not least for those living in the mixed, multi-generational households that have proved to be one of the main vectors of transmission of SARS-CoV-2. Which is why some UK doctors have been working with the hospitality industry to try and provide space for those who don't have it, to slow the spread of the virus.

"There are people who need to isolate but are struggling to do so because of a number of factors, such as living in shared accommodation," says Akbar 
de' Medici, honorary associate professor at University College London, and medical director of Cavendish Health Concierge.

De' Medici has been working with the hotel chain Best Western to train hotel staff in infection control and prevention, should they be asked to step in to support hospitals. The partnership sprang up during the first wave of SARS-CoV-2 in the UK, with two or three hotels around London working with local hospitals to offer NHS staff quarantine space, and another housing the homeless to try and prevent street spread.

But in the second wave there has been minimal action from the government to repeat the experiment, despite England entering its third national lockdown.

"Everyone's concentrating on the vaccine, test and trace is not as proactive as it was before, and the government's focus has shifted away from these simple, short term solutions,” says de' Medici.

The hotel industry has 20-30 ooo unused hotel beds that could be converted into isolation hubs. "We've got 10 months of learning and putting together structures and protocols to manage covid positive patients," says Rob Paterson of BWH Hotel Group, which runs Best Western hotels.

Paterson likens the effort to Dunkirk, where small UK boats helped evacuate troops from France during the second world war. More than 500 hotels are waiting to accept homeless, covid positive patients needing step-down care, NHS staff looking to distance safely from their family while working, and those who have been asked to self-isolate but would find it difficult to do so from home, he says.

He reckons 5000 rooms could be prepared within 72 hours of being asked. The hotels are fully insured to handle patients and staff, and hotel workers have been trained to clean and work in a way that minimises risk of spread (only cleaning whole floors and only when empty, for instance). The whole enterprise is charged at cost with no profit made.

The UK government's response to the proposal has been muted, however. Hotel isolation is being implemented but only for a small number of international travellers arriving in the UK from certain countries where cases are high. It's a policy the Labour Party has called "half baked."

\section{Following China}

The reticence to rely on hotels is despite institutional self-isolation working. "In Wuhan, they pulled out every single weapon in the armoury against respiratory diseases," says Annelies Wilder-Smith, professor of emerging infectious diseases at the London School of Hygiene and Tropical Medicine. "But the true decline to zero was because they also isolated all mild cases. Every case that tested positive was isolated."

The stories of China building hospitals from scratch reported in the early stages of the pandemic were a misconception: while they were called hospitals, they were largely makeshift shelters. Just last month, the country built a quarantine camp for 4000 people on the outskirts of Shijiazhuang, the provincial capital of the province that surrounds Beijing. ${ }^{1}$

China and other Asian countries like Singapore have managed to control the spread of the virus by doing similar and hospitalising positive cases. That costs money, "but they do it, because they know nobody is totally capable of isolating themselves from other household members," says Wilder-Smith.
And that's the reality the UK and other European countries-lurching from one lockdown to another while never really stemming the spread of the virus-need to wake up to. ${ }^{2}$ Closing schools, shops, and workplaces is only solving half the problem. People with mild symptoms shed the same amount of virus as severe cases, with some variation, and people aren't perfect in adhering to social distancing and isolation rules, even in their own home. It is almost impossible to adhere fully to social distancing if you're living in crowded or inadequate accommodation.

With colleagues, Wilder-Smith modelled what impact facility based isolation for all cases could have on the spread of disease. Offering five isolation beds per 10 ooo people could reduce new infections by $57 \%$, and deaths by more than a third.

But even if they were offered a place to stay away from family, the potential loss in income would be such that many might reject the offer, which is why it needs to be coupled with financial support. "The problems that happen during the period of isolation don't go away, so being able to link to other financial support or mental health support is important," says Marquez. It's a model that other cities in the US have also followed, including New York which also has a city government run programme offering a hotel room, free of charge, for up to 14 days if they do not have a safe place to self-isolate (for instance if they share a bathroom, live with someone considered vulnerable, or do not have space to stay six feet distanced).

"The financial support, the wraparound services, and the human connection can convince people to do things that are really hard," she says, "because a lot of times that three days of lost wages can tip you over the edge."

Competing interests: I have read and understood BMJ policy on declaration of interests and have no relevant interests to declare.

1 Yeung J. China builds massive covid-19 quarantine camp for 4000 people as outbreak continues. CNN. 21 January 2021. https://edition.cnn.com/2021/01/20/asia/china-shijiazhuang-covid-quarantine-intl-hnk-scli/index.html.

2 Pagel C. Covid-19: How to break the cycle of lockdowns. BMJ Opinion. 27 January 2021. https://blogs.bmj.com/bmj/2021/01/27/covid-19-how-to-break-the-cycle-of-lockdowns.

This article is made freely available for use in accordance with BMJ's website terms and conditions for the duration of the covid-19 pandemic or until otherwise determined by BMJ. You may use, download and print the article for any lawful, non-commercial purpose (including text and data mining) provided that all copyright notices and trade marks are retained. 